\title{
The Camel today: assets and potentials
}

\author{
Bernard FAYE \\ CIRAD-ES Campus International de Baillarguet TA C dir/B, \\ F-34398 Montpellier (France) \\ bernard.faye@cirad.fr
}

KEY WORDS

Large camelids, physiological adaptability, agro-ecosystem arid lands.

MOTS CLÉS

Les grands camélidés, adaptabilité physiologique, systèmes agro économiques des terres arides.
Faye B. 2014. - The Camel today: assets and potentials. Anthropozoologica 49 (2): xx-xx. http://dx.doi.org/10.5252/az2014n2a01.

\begin{abstract}
Although they quantitatively only take a marginal place amongst domestic herbivores (only $0.4 \%$ of world domestic herbivores), the large camelids (dromedary and Bactrian) are present in almost all the arid lands of the old world (except in Southern Africa), a widespread area of over 35 millions $\mathrm{km}^{2}$. They are overall remarkable enhancer of these spaces by their productive potential and by their role in the agro-ecosystemic balance of the arid lands, especially with the current climatic changes. Elsewhere, they are known for their physiological peculiarities linked to their adaptation ability to harsh conditions of the desert and of its margin. In consequence, they represent a fabulous biological model for the scientists from different disciplines. Their place in the "modern world" has to be re-evaluated by considering these trends and these particularities.
\end{abstract}

\section{RESUME}

Les chameaux aujourd'hui: atouts et potentiels.

Bien qu'occupant une place marginale parmi les herbivores domestiques $(0,4 \%$ de la population mondiale des herbivores domestiques), les grands camélidés (dromadaire et chameau) sont présents dans pratiquement toutes les terres arides du monde (sauf le sud de l'Afrique) sur une étendue de plus de 35 millions

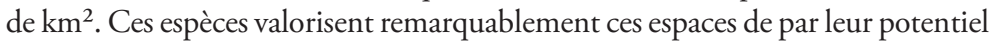
productif et de par leur rôle dans l'équilibre des systèmes agro économiques des terres arides, spécialement avec les présents changements climatiques. Ailleurs, ils sont connus pour leurs particularités physiologiques en relation avec leur pouvoir d'adaptation aux conditions désertiques et ses marges. Par conséquent, ils représentent un modèle biologique fabuleux pour différentes disciplines. Leur place dans le «monde moderne » doit être reconsidéré en tenant compte de ces particularités. 


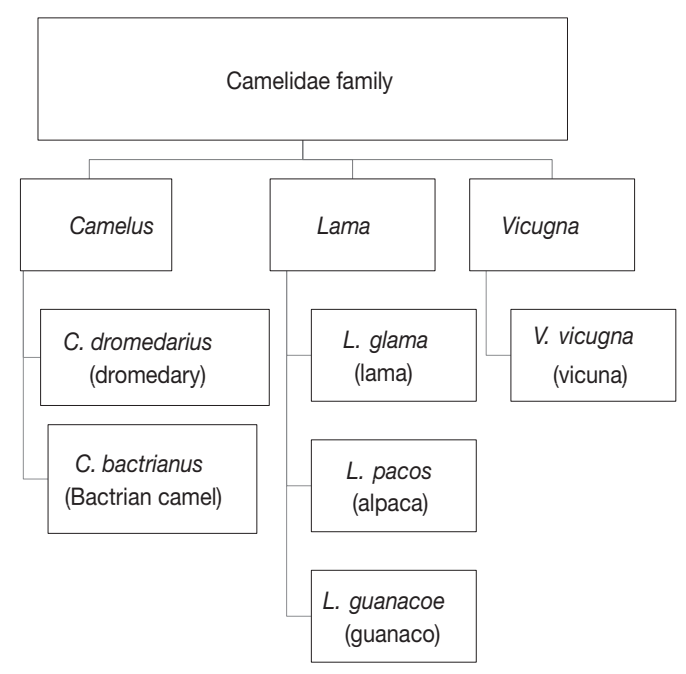

FIG. 1. - Classification of the Camelidae family.

\section{INTRODUCTION}

The camel belongs to the camelidae family of mammals among the order of Artiodactyles and to the sub-order of tylopoda (animals with padded feet). Thus, they are different from the ruminants (especially bovinae family): in spite of the camel is being a ruminating animal, it is not a ruminant. The family of camelidae is comprised of two main types (large and small camelids) distributed into three genera: Camelus, Lama and Vicugna (Fig. 1).

The small camelids originate from the Andes Mountains of South America and include two domestic species (lama and alpaca) and two wild species (guanaco in the genus lama and vicuna in genus vicugna). The large camelids are represented by two domesticated species the one-humped camel (dromedary) and the two-humped camel (Bactrian camel), the first living in the hot arid lands from North of Africa and eastern part of Asia, the second in the cold steppes and deserts in Central Asia. Some authors have described a further large camelid species. This is a wild species living in very remote areas between Mongolia and China, called Tartary camel (C. bactrianus ferus) which was distinguished from the domestic double humped camel (Ji et al. 2009).

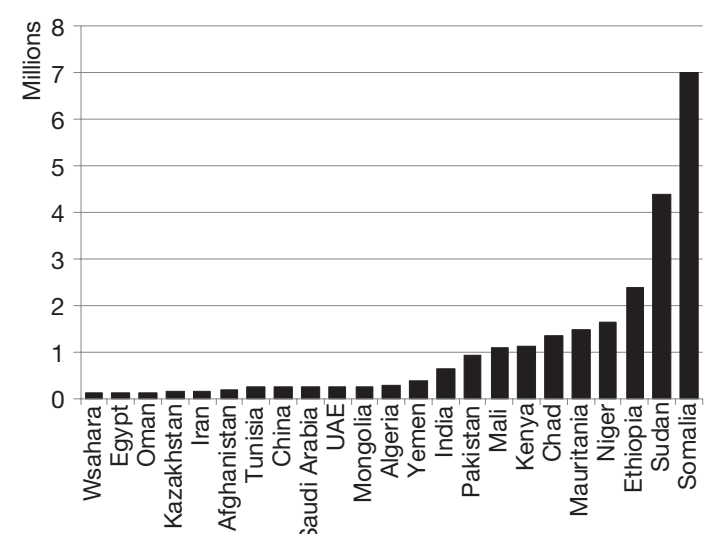

FIG. 2. - Number of camel in the countries having more than 0.1 million camels.

Thus, the camelidae family is characteristic of animals occupying remote areas, arid lands or high mountains. This is linked to the high adaptation of those species to their ecosystem. This explains the interest of this family for maintaining rural activities in the most inhospitable places of the planet.

The present paper deal with the importance of camelids in the world today, their role with human populations, their potential production value for the local economy, as well as their integration into the international economy.

\section{THE CAMEL WORLD DISTRIBUTION}

It is difficult to exactly determine the number of camels in the world, firstly, because it is mainly an animal of nomadic people and pastoralists who are moving frequently, and secondly, because camels are not usually subjected to obligatory vaccination. So, an exhaustive census for the camels is quite difficult. Officially, the total number of camels in the world was around 27 million heads (FAOstat 2014). This number is probably underestimated. Particularly, in the Sahelian countries (Mauritania, Mali, Niger, Chad, Sudan, Ethiopia) when the number of camel heads was adjusted after appropriate census, it appeared a quite higher number increasing the former estimation of the population. For instance, in Chad 


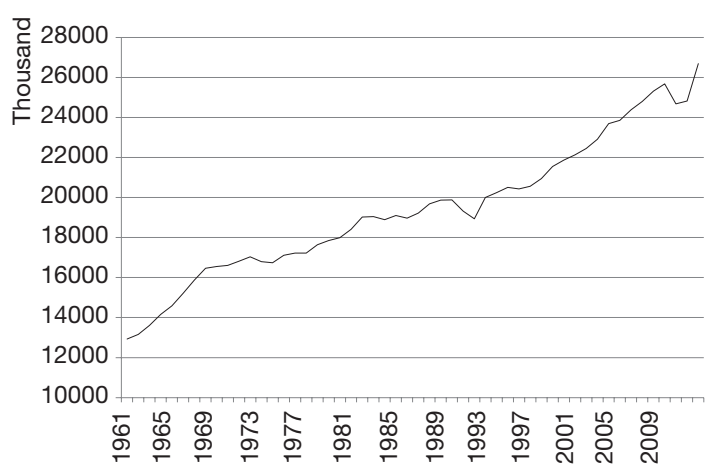

FIG. 3. - Camel world population growth between 1961 and 2009.

the camel population was readjusted from 800,000 to more than 1.3 million heads after appropriate census by the Ministry of Animal Resources. Thus, by considering both the wild Australian camel population (Gee 1996) and the different national estimations, the camel world population is probably around 30 million heads. However, as a whole, this population represents less than $1 \%$ of the total herbivorous domestic population in the world, far away behind cattle (1.5 billions) sheep and goat (more than one billion each), and even behind horse (70 million) and buffalo (200 million).

More than $80 \%$ of this population lives in Africa with $60 \%$ in the Horn of Africa. The most important countries for camel economy with a camel population over 1 million are in the order: Somalia, Sudan, Ethiopia, Niger, Mauritania, Chad, Kenya, Mali, and Pakistan (Fig. 2). The world camel population is increasing regularly with a yearly growth of $2.1 \%$. Since 1961 (date of the first FAO statistics) the world camel population has more than doubled (Fig. 3). However the growth rate was not similar for all the countries. We can distinguish 5 types of trends:

- Countries with high recent growth (Algeria, Chad, Mali, Mauritania, Oman, Qatar, Syria, UAE, Yemen, Ethiopia, Eritrea).

- Countries with regular growth (Bahrain, Burkina Faso, Djibouti, Egypt, Iran, Kenya, Niger, Nigeria, Pakistan, KSA, Somalia, Sudan, Tunisia, Western Sahara).

- Countries with stable population (Lebanon, Libya and Senegal).

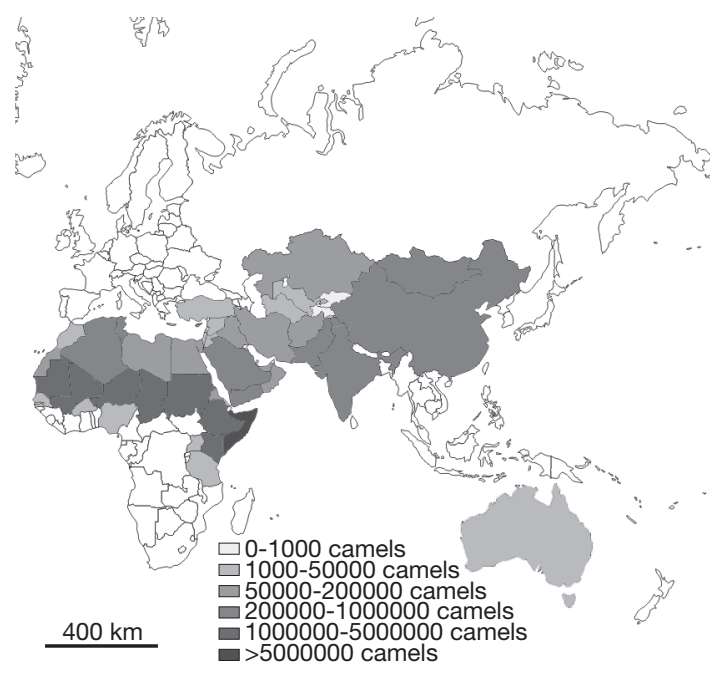

FIG. 4. - Camel distribution of the world (FAOstat 2013).

- Countries with declining population (Afghanistan, China, India, Israel, Jordan, Mongolia, ex-SovietUnion, republics from Central Asia).

- Countries with high rate of decline (Iraq, Morocco, Turkey).

The dromedary is obviously linked to the arid countries and on sociological aspects mainly (but not exclusively) to Muslim countries (Fig. 4).

In countries with a desert environment (e.g. Mauritania, Saudi, Arabia Gulf countries, Persian to Gulf countries), the camel farming systems are found all over the country, but only a small space is devoted to camel rearing in sub-arid countries. For instance in India, only the north-western area (Rajasthan and Gujarat states) is favourable for camel farming. In Ethiopia, only the lowlands (below $1500 \mathrm{~m}$ altitude) are regularly occupied by camels. Similar patterns are observed for Bactrian camel. For instance in China and Kazakhstan, the Bactrian camel is present only in the arid part of the country (Gobi desert in China and MoyoumKoum desert in Kazakhstan).

The camel was introduced in other countries, either for leisure as in circus or zoological gardens, or for rearing in multipurpose activities such as: touristic attraction, walking in remote places, beaches and sometimes for milk production. Some camel farms in 

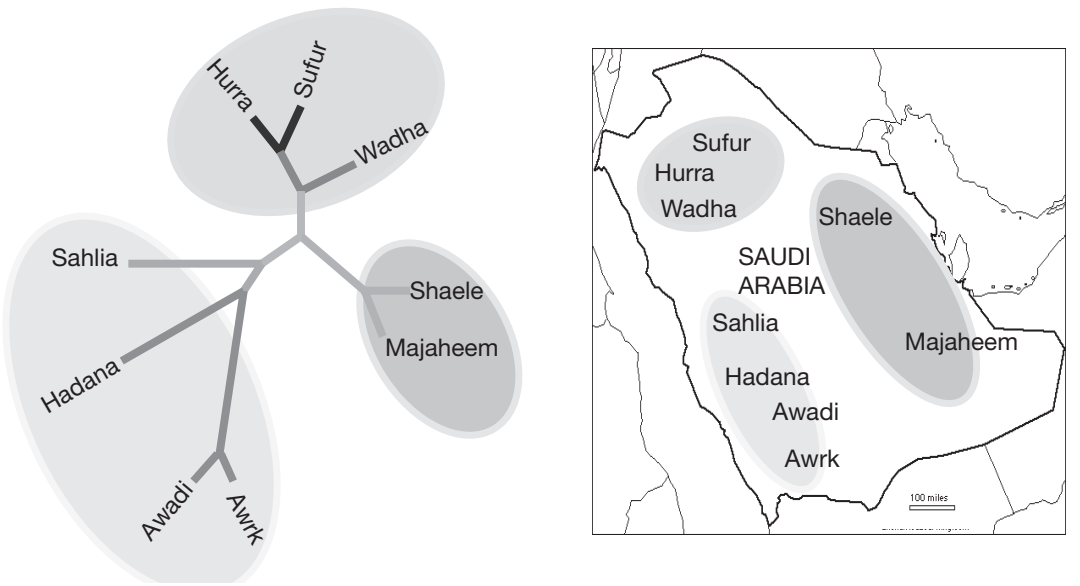

FIG. 5. - Left: Phylogenetic tree of camel populations in the Kingdom of Saudi Arabia using microsatellite markers. Right: Location of the three camel population groups in Saudi Arabia.

Western Europe (Faye et al. 1995) or in North America were established, but its significance remains quite marginal. Even the dromedary introduction to SouthAfrican desert (Kalahari) was poorly developed. The main success of camel introduction out of its original home countries was in Australia but the major part of the herd is now feral (Faye et al. 2002). With a wild camel estimated population of approximately $1 \mathrm{mil}-$ lion heads, the camel in Australia is regarded mainly as a big environmental problem in the Central desert area of the country rather than a potential source of meat (Saalfeld \& Edward 2010).

\section{CAMEL BIODIVERSITY}

The selection pressure on camel is low. Except for keeping animals for a specific purpose (packing, riding, milking), few selection programmes by choosing the best animals according to the performances of their descendants were implemented, except for racing animals. However, at the world level, a high variability is observed although a high confusion is reported. Indeed, several breed names could be given for the same type of animals. Some denominations could make reference to the coat colour only or different breeds could be described on the base of the tribe name of the owner. In a relative old publication
(Blanc \& Ennesser 1989), 48 dromedary breeds were described in the world and classified into 8 sub-groups according to their phenotypes, but this classification was based only on the general conformation of the animals. Finally, if the camel biodiversity is attested by many authors, it is not properly described up to now at the world level. The results based on molecular genetic attested the high confusion in the camel biodiversity description. Thus, the different phenotypes described in Kenya appeared without genetic differences (Jianlin et al. 2000) as well as in Tunisia (Chniter et al. 2013). In Saudi Arabia, 9 camel phenotypes are described (Fig. 5), but after analysis by molecular genetic, only 3 sub-types were identified (Faye et al. 2011; Almathen 2014).

\section{THE CAMEL, A MULTIPURPOSE ANIMAL}

The camel is a multipurpose animal. It can be used for milk, meat, wool, transport, race, tourism, agricultural work and beauty contest. No other domestic animal is able to provide such a variety of uses to human populations. Meat and skin production are the only purposes which require the camel to be slaughtered. Consequently, meat production is linked to proper herd management in terms of selection of animals to be slaughtered 
such as young males which are not kept for reproduction or other activities and culled female or males and to market organization at local and regional levels. Milk production is the principal purpose for camel rearing in many countries, especially for dromedaries (the dairy yield of Bactrians is lower). The consumption of camel milk is common as the camel is mainly reared in remote areas. The quality of camel wool is widely variable. It is better in countries having cold winters and Bactrian wool is more appreciated. In Mongolia, some breeds were selected for wool production, giving fiber as cashmere. The camel is used for riding but also for racing. The camel race is an important cultural event in the Arabian Peninsula and has also become popular in Africa. Historically the ability of camels to be ridden was utilised by armies, and today a number of Sub-Saharan countries still use camels for their military campaigns. Camel power is used primarily though for peaceful means for transport (as draught animals). The use of camel in caravans through the desert is a popular image, but is still operational in some areas. Draught camels are common in India for transportation of all kinds of industrial or agricultural goods. The camel is also an auxiliary of agricultural activities for ploughing, water extraction, seeding, harrowing etc... The use of camels at tourist attractions is developing, not only for riding on beach, dunes or around the pyramids in Egypt, but also for festival, fantasia and other spectacles like the dancing camel at Pushkar Fair (India). In Abu Dhabi in the United Arab Emirates, an important event occurs for evaluating the beauty of the camel with high value awards for the winners.

\section{FROM TRADITION TO MODERNITY}

Traditional camel farming systems are extensive, based on the use of natural resources and on the herd mobility. The biological particularities of camels means that they have a very slow reproductive cycle: long gestation (13 months), late precocity for reproduction (rarely before 3 years), long inter-calving interval (generally 2 years). Moreover, the survival rate of the young being low (the young mortality could reach $20 \%$ and even more), the numerical productivity is weak, even if the longevity of the camel could compensate it. Yet, the traditional camel farming systems show a very high variability, showing the possibility for important productivity progress. This potential could be used to intensify the camel productivity through intensified systems. Some examples are available in the field of milk and meat production showing the ability to develop "modernized" farming systems for camels (Breulmann et al. 2007).

\section{DAIRY POTENTIAL}

Milk is one of the main products from camels with a high interest for local population in arid lands for at least 3 reasons: (i) the main part of the production is self-consumed and thus, contributes to the food security of arid lands, (ii) there is a growing interest for camel milk from the urbanized population in those areas and then an increasing market opportunity, (iii) there is a trend to the development of dairy camel intensive system which could be profitable for settled producers (Faye et al. 2002; Faye \& Konuspayeva, 2012). However, as camel milk is still not widely integrated into national markets (except in some countries like Mauritania Kenya Emirates or Saudi Arabia) the official statistics could be debatable. According to available FAO statistics, camel milk production increased by $6.72 \%$ yearly, i.e. more than the camel population. Passing from 629,148 tons in 1961 to $2,785,382$ tons in 2008 , the camel milk production has multiplied by 4.4 . At a world level, camel milk represents $0.37 \%$ of the consumed milk but this proportion is probably underestimated: On the base of $16 \%$ of lactating animals producing on average $1500 \mathrm{l} /$ lactation the milk production by camels could be estimated to be 6 million tons.

The increase in dairy production by camels was due to 2 facts: (i) the slight increase of the proportion of lactating animals in camel herds passing from 14.7 to $22.8 \%$ between 1961 and 2012, (ii) camel population growth. However, the increase in camel milk production is not due to the improvement of the dairy productivity. Compared to cattle and buffalo, the investigation of research and development 


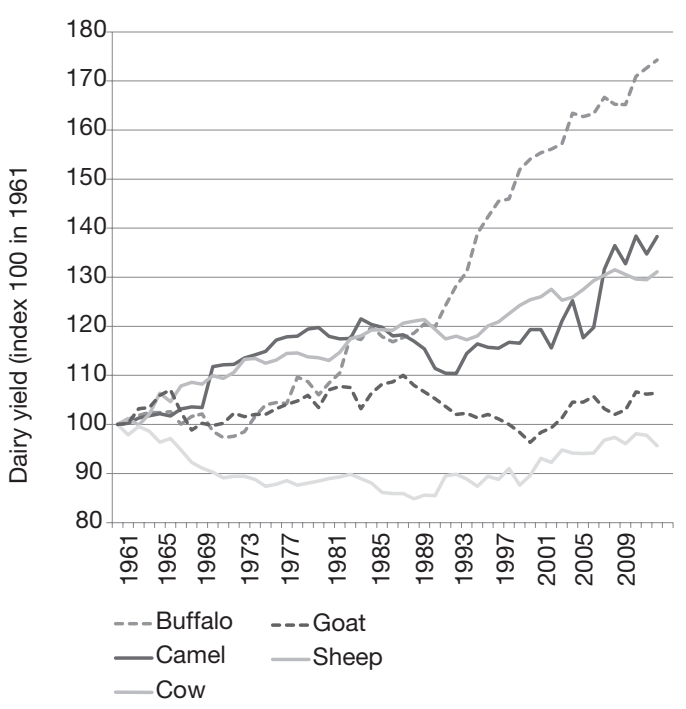

FIG. 6. - Change in dairy yield /animal from 1961 to 2009.

was not sufficient to increase the dairy yield in camel (Fig. 6) in spite of its high potential. It is probably the main point regarding milk production in camel: an important potential for increasing dairy yield in camel is existing, but this potential is not widely supported by research programs (Faye 2004; Faye \& Konuspayeva 2012).

In spite of this slow change in dairy productivity at world level, some significant trends are observed:

The camel milk market integration is developing. For most of the pastoralists, camel milk cannot be sold because it is a gift. This cultural behaviour was the main obstacle for implementing a camel milk market (Abdeirahmane 1997). However, with the urbanization of population formerly living in pastoral areas, the camel milk demand increased, encouraging the implementation of periurban camel farming systems integrated to local markets (Faye et al. 2003).

Traditionally consumed under fresh or fermented form, the processing of camel milk into cheese was difficult. However, several technological researches were achieved for performing cheese making (Boudjenah-Haroun et al. 2011; Konuspayeva et al. 2014) and other dairy products (ice cream, yoghurt). Nowadays, camel cheese production is available in few countries.

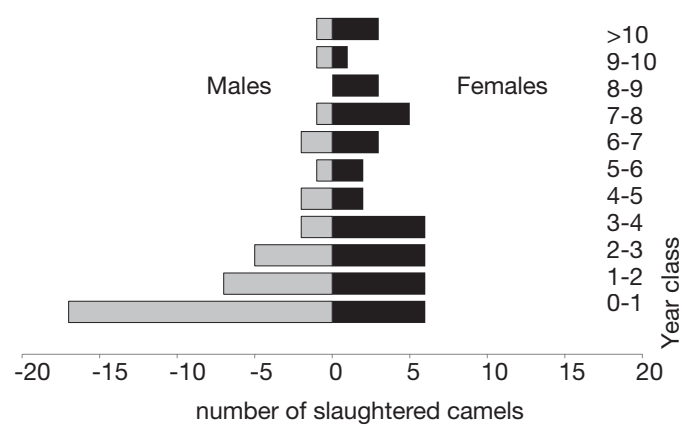

FIG. 7. - Age pyramid of the slaughtered camels at the Laâyoune abattoir (Morocco).

The use of milking machines is developing in big size farms (Emirates, Saudi Arabia, Central Asia) and the camel shows a convenient adaptation to automatic equipment without significant effect on udder health (Ayadi et al. 2013).

The development of the camel milk market is linked to the implementation of dairy plants able to process camel milk like the Tiviski factory in Mauritania (Mohammed 2003).

The intensification of the reproductive cycle of camels is based on the advent of biotechnology of reproduction and new farming practices like artificial insemination, embryo transfer, early weaning or artificial milking of the young (Tibary \& Anouassi 1997).

The implementation of genetic selection program for racing performance (in the United Arab Emirates) or for milk production improvement was developed in Central Asia (Tasov \& Alybaev 2004).

\section{MEAT PRODUCTION AND MARKET}

The available statistics on camel meat production in the world are limited to the number of slaughtered animals, the mean carcass weight upon which meat production is estimated. However, there is no available statistics on the type of camels slaughtered or meat processing. A significant number of camels are slaughtered out of official channels and they are unaccounted for suggesting that camel meat production is probably under-estimated.

The percentage of slaughtered camels has regularly increased since the year 1960 ranging from 5 to $7 \%$. 
This increase could be explained by a better organization of the camel meat commodity channels and a decrease of the unofficial slaughtering although unofficial slaughtering in camels is less important than for small ruminants or even for cattle. Indeed, the heavy weight of the camel does not usually encourage killing one animal for few guests contrary to goat or sheep. The slaughtering rate is obviously higher in male than in female camels. Only local statistics are available for camel meat production. For example in the slaughterhouse of Laâyoune (South-Morocco/ Western Sahara) the observation of the age pyramid of slaughtered animals for 5 months monitoring (Faye, unpublished results) have shown that $44 \%$ of the slaughtered males were less than one-year old vs. $14 \%$ of the females. The culled adult females represented $28 \%$ of the slaughtered females vs. $7.7 \%$ only for adult culled males (Fig. 7). From 1961 to 2012, camel meat production increased at a rate of $4.6 \%$ from 123.000 to 415.524 tons. The more important camel meat producers are Sudan, Egypt, Saudi Arabia (KSA) and Somalia, but some of these countries are mainly exporting (Sudan, Somalia) while others are rather importing (KSA, Egypt). In spite of the low contribution of camel to the world meat production it is noticeable that the growth is higher than for cattle sheep and horse meat. Using the index 100 in 1961, the index of meat production in 2012 was 475 for goat, 329 for buffalo, 337 for camel, 227 for cattle, 166 for sheep and 125 only for horse (Fig. 8).

The contribution of camel meat to world meat production is rather marginal due to the less significant place of camel among the herbivores. Compared to all meat producing types (except fish), camel meat represents $0.13 \%$ of the total meat produced in the world and $0.51 \%$ of red meat from herbivorous. However, contrary to milk which is only integrated into local markets, the camel meat is involved in international markets, especially in the Horn of Africa (Faye, 2013a).

Regarding the camel meat sector the improvement of the market is based on the following items: - The implementation of camel feed-lots for encouraging the delivery of very well fattened animals on the market is increasing.

- Specialized butcheries for camel meat marketing have been implemented in North Africa (Tunisia Morocco) in order to satisfy the urban demand.

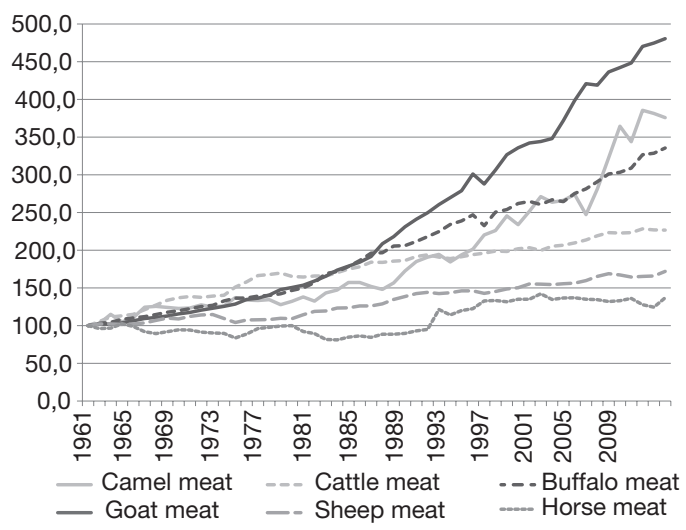

FIG. 8. - Growth of the red meat production in the world since 1961 (index 100).

- The official slaughtering of camels is increasing in most of the countries and proposals for carcass classification meat quality evaluation convenient cutting better veterinary control are more and more frequent.

- New camel meat products are available on the urban market like "camelburger" sausages and corned camel in a tin (Farah \& Fisher 2004).

\section{OTHER PURPOSES}

In spite of the rapid urbanization in the camel countries the interest of camel for cultural events is increasing. The camel race is still very popular in gulf countries especially. This activity has pushed much innovative research on genetic, biotechnology, physiology and contributes to a better understanding of camel biology.

\section{THE CAMEL IN THE FACE OF CLIMATIC CHANGES}

That point is particularly important to understand the present trend on the expansion of camel farming systems in Africa and Asia. All the authors in the scientific literature stress on the ability of camel to survive in desert ecosystems, and underline the physiological particularities testifying its 
adaptation to arid conditions (Bengoumi \& Faye 2002). The camel is belonging to the domestic species characterized by hyper-adaptation to a given milieu leading to a low plasticity (as for yak, reindeer or llama) but essential for keeping rural activities in remote areas. The indirect effects of the climatic changes on animal were described by some authors underlining the impact on feed resources (including water) and on diseases (Sirohi \& Michaelowa 2007). In Sahelian countries, the climatic changes observed from meteorological reporting since one century are characterized sometimes by severe droughts more marked than in the past and sometimes (especially in recent times), by very abundant rainfall over shorter periods of time. These changes have some effects on camel stock and breeding both on their geographical distribution, their health status and on their social use by the farmers. Four main aspects could be observed in Sub-Saharan Africa: (i) a tendency for a camel population increase in settled livestock farming systems, (ii) a tendency to the use of camel as auxiliary of agriculture, (iii) a more close market integration of the camel commodity channel, (iv) an increased role of camel in the security of farming systems traditionally focused on cattle breeding.

Of course, the proper dynamic characteristic of the pastoral societies and the global economy have also an impact on the observed evolutions as well on progressive market integration, as on the emergence of new pathologies. But, the indirect effects induced by the pressure of the climatic changes on the space occupation and, consequently, on the relationship between social and economic use, resources management, interaction with the environment and epizootiological risks cannot be ignored (Faye et al. 2012) as the recent outbreak of MERS-CoV in Saudi Arabia as shown (Arsevska et al. 2014).

\section{THE TRENDS IN CAMEL SCIENCES}

According to the number of publications focused on camelids each year, we can consider that the interest of the international scientific community still exists. The trend is to a slight increasing of the scientific production since 30 years. However, the camel studies are still quantitatively marginal compared to other ruminant species. This marginality is linked first to the low camel stock compared to cattle for example, and to the limited geographical distribution of this species. Secondly, for funding agencies and main decision makers, camel is rarely considered as a productive animal, but rather as an animal from the past, just interesting to walk in the desert with the tourists (Faye \& Brey 2005). So, the scientific interest of camel appears to be low for many research institutes in the North and even in the southern countries. For example, in sub-Saharan African countries, development projects and research interest increased first for political reasons after different periods of rebellion of nomads traditionally camel keepers (Mali, Niger, Chad, Morocco...). But in the same time, as it has been shown above, camel farming is engaging into intensification process for dairy and meat production. Elsewhere, the camel appeared as a very interesting biological model for scientists in different fields. The international scientific community must be aware of these trends, and the camel scientists, especially in the southern countries, contribute to the promotion of new scientific approaches. A short analysis of these new trends in camel sciences is presented below. However, the camel scientists have to stay modest. From 1779 up to 2014, no more than 12,000 official publications are available in camel sciences field, which is more or less the total number of references for cattle into three years. Nevertheless, the present trends could be observed and are encouraging for camel scientists: - The camel interests the scientists as biological model: adaptation to extremes conditions, bioactives molecules in milk as Lactoferrin or lyzozymes (Konuspayeva et al. 2006), exceptional particularities of the immunoglobulins (Hamers-Casterman et al. 1993), medicinal properties of camel milk (Konuspayeva et al. 2004) etc...

- The camel has shown its high productive potential in arid conditions (milk meat wool energy...) but the progress was slow in the last decades. However recent research has supported new considerations regarding the productivity of camels (Faye 2004; Kadim et al. 2008). 
- The camel is an element of arid ecosystems and global change could conduct a change in farming systems to the appearance of emerging diseases and could underline the adaptation of camel face to climatic changes. All these aspects are more and more taken in account by the camel sciences (Faye 2013b).

\section{CONCLUSION}

The camel is a marginal animal at the world level which still has an old fashioned image. Yet, the main aspects to be underlined on camel today are the followings:

- The camel is able to produce milk, meat and wool in very harsh conditions with a high added value for the producers and interesting dietetic and nutritive properties for the consumers.

- The camel is no more only the ship of desert but also a productive animal able to be involved in intensification processes and in consequence, in modern farming systems.

- Camel rearing is expanding in the world especially in Africa and the camel population is still growing. - The camel has its place for the future, notably with the climatic changes.

- The organization of the camel scientists' community through the International Society of Camelid Research and Development -ISOCARD (www. isocard.org) is an important step for supporting the acknowledgement of the camel sciences.

\section{REFERENCES}

Abdeirahmane N. 1997. - Camel milk and modern industry. Journal of Camel Practice and Research 4: 223-228.

Almathen F. 2014. - Genetic diversity and demographic history of the dromedary camel (Camelus dromedarius). $\mathrm{PhD}$ thesis submitted to the Universitry of Nottingham (UK), March 2014, 245 p.

Arseviska E., Calavas D., Esmaile De Sales lima F., Faye B., Hendrikx P., Lancelot R., Lefrancois T. \& LiBEAU G. 2014. - Coronavirus du syndrome respiratoire du Moyen-Orient (MERS-CoV) : quel réservoir animal? Bulletin Epidemiologie-Santé animale., Alimentation, Bilan sanitaire, http://www.
ansespro.fr/bulletin-epidemiologique/Documents/ Breve-MERS-CoV_2402.pdf

ayadi M., Aljumaah R. S., Musaad A., Samara E. M., Abelrahman M. M., Alshaikh M. A., Saleh S. \& FAYE B. 2013. - Relationship between udder morphology traits, alveolar and cisternal milk compartments and machine milking performances of dairy camels (Camelus dromedarius). Spanish Journal of Agricultural Research 11 (3) : 790-797

Bengoumi M. \& Faye B. 2002. - Adaptation du dromadaire à la déshydratation. Revue Sécheresse 13: 121-129.

BLANC C.P. \& ENNESSER Y. 1989. — Approche zoogéographique de la différenciation infraspécifique chez le dromadaire Camelus dromedarius Linné, 1766 (Mammalia : camelidae). Revue d'Elevage et de Médecine Vétérinaire des Pays Tropicaux (Paris) 42(4): 573-587.

Boudjenah-Haroun S., Laleye C. L., Moulti-Mati F., Si Ahmed S., Mahboub N., Siboukeur O. E. \& MATI A. 2011. - Comparative study of milk clotting activity of crude gastric enzymes extracted from camels' abomasum at different ages and commercial enzymes (rennet and pepsin) on bovine and camel milk. Emirates Journal of Food and Agriculture 23(4): 301-310. doi:10.9755/ejfa.v25i8.16096.

Breulmann M., Boer B., Wernery U., Wernery R., El-Shaer H., Alhadrami G., Gallacher D., PeaCOCK J., Chaudhary S. A., Brown G. \& Norton J. 2007. - The camel, from tradition to modern times. Unesco Doha Publ., Doha (Qatar).

Chniter M., Hammadi M., Khorchani T., Krit R., BenWAHADA A. \& Ben Hamouda M. 2013. - Classification of Maghrebi camels (Camelus dromedarius) according to their tribal affiliation and body traits in southern Tunisia. Emirates Journal of Food and Agriculture 25 (8): 625-634

FARAH Z. \& FisHER A. (eds). 2004. — Milk and meat from the camel: handbook on products and processing. Publ. VDF Hochschulverlag AG et ETH Zurich Suisse.

Faye B., Grech S. \& Korchani T. 2002. - Le dromadaire entre féralisation et intensification. Anthropozoologica 39 (2): 7-13.

FAYE B. 2004. - Dairy productivity potential of camels. Proc. of the 34 th meeting FAO/ICAR (International Committee for Animal Recording). Session on camelids. 28 mai-3 juin 2004, Sousse (Tunisie): 93-105.

Faye B., Jouany J. P., Chacornac J.P. \& RatovonaNAHARY M. 1995. — Lélevage des grands camélidés. Analyse des initiatives réalisées en France. INRA Productions Animales 8: 3-17.

Faye B., Bengoumi M. \& Barkat A. 2003. - Le développement des systèmes camélins laitiers périurbains en Afrique. Atelier Int. sur le lait de chamelle en Afrique. FAO-CIRAD-KARKARA Niamey (Niger) 5-8/11/03: 115-125.

FAYE B. \& BREY F. 2005. - Les relations entre chameaux 
et société: entre marginalisation et idéalisation. Revue Ethnozootechnie 77: 43-50.

Faye B., Abdallah H., Almathen F., Harzallah B. \& Al-Mutairi S. 2011. - Camel biodiversity- Camel phenotypes in Saudi Arabia. FAO publ. Camel Breeding, Protection and Improvement Center, project UTF/SAU/021/SAU, FAO publ., Riyadh (Saudi Arabia), 78 p.

FaYe B. \& KonUSPAYEVA G. 2012. - The sustainability challenge of the dairy sector- The growing importance of the non-cattle milk production worldwide. International Dairy Journal 24: 50-56

Faye B., Chaibou M. \& Vias G. 2012. — Integrated impact of climate change and socioeconomic development on the evolution of camel farming systems. British Journal of Environment and Climical Change, 2 (3): 227-244

FAYE B. 2013a. - Camel meat in the world. In: "Camel meat and meat products", KadiM I., MaghOUB O., FAYE B. \& FAROUK M. (eds), CAB International, Oxfordshire, UK, 7-16.

FaYe B. 2013b. - Camel Farming Sustainability: The Challenges of the Camel Farming System in the XXIth Century. Journal of Sustainable Development., 6 (12): 74-82

GEE P. 1996. - The camel in Australia. Journal of Camel Practice and Research 3 (2): 139-140.

Hamers-Casterman C., Atarhouch T., Muyldermans S., Robinson G., Hamers C., Songa E. B., Bendahman N. \& Hamers R. 1993. - Naturally occurring antibodies devoid of light chains. Nature 363: 446-448.

Ji R., Cui P., Ding F., Geng J., GaO H., Zhang H., Yu J., Hu S. \& Meng H. 2009.- Monophyletic origin of domestic bactrian camel (Camelus bactrianus) and its evolutionary relationship with the extant wild camel (Camelus bactrianus ferus). Animal genetics 40: 377-382.

Jianlin H., Mburu D., Ochieng J., Kaufmann B., Rege J. \& HanotTe O. 2000. - - Application of new world Camelidae microsatellite primers for amplification of polymorphic loci in Old World Camelids Animal genetics 31: 404-406.

Kadim I. T., MahgOUB O. \& PURCHAS R.W. 2008. A review of the growth, and of the carcass and meat quality characteristics of the one-humped camel (Camelus dromedaries). Meat Science 80 : 555-569.

Konuspayeva G., Loiseau G. \& Faye B. 2004. La plus-value "santé » du lait de chamelle cru et fermenté : l'expérience du Kazakhstan. Renc. Rech. Ruminants 11: 47-50.

Konuspayeva G., Faye B., Loiseau G. \& Levieux D. 2006. - Lactoferrin and Immunoglobin content in camel milk from Kazakhstan. Journal of Dairy Science $90: 38-46$.

Konuspayeva G., Camier B., Gaucheron F. \& Faye B. 2014. - Some parameters to process camel milk into cheese. Emirates Journal of Food Agriculture, 26(4): 354-358

MoHAMmed A. 2003. - Organisation d'un réseau de collecte de lait en Mauritanie. Atelier Int. sur le lait de chamelle en Afrique. FAO-CIRAD-KARKARA Niamey (Niger) 5-8/11/03: 104-112.

SAALFELD W. K. \&EDWARD G. P. 2010. - Distribution and abundance of the feral camel (Camelus dromedarius) in Australia. The Rangeland Journal 32: 1-9.

Sirohi S. \& Michaelowa A. 2007. - Sufferer and cause : Indian livestock and climatic change. $\mathrm{Cli}$ matic change 85: 285-298

Tasov A. \& Alybaev N. - Camel Genetic resources and ways of camel breeding products use for population of Kazakhstan arid areas. Proceedings of the International Workshop "Desertification combat and food safety : the added value of camel producers". Ashkhabad (Turkmenistan) 19-22 April 2004. In "Vol. 362 NATO Sciences Series Life and Behavioural Sciences". FAYE B. \& Esenov P. (eds), IOS press Publ. Amsterdam (The Netherlands): 128-130.

TiBARY A. \& ANOUASSI A. 1997. - Theriogenology in camelidae. Anatomy, physiology, pathology and artificial breeding. Actes Ed. IAV Hassan II Morocco.

Submitted on January 2013; accepted on March 2013. 